\title{
ПРОЦЕДУРА РАЗРАБОТКИ И РЕАЛИЗАЦИИ НАЦИОНАЛЬНЫХ ПРОЕКТОВ И НАЦИОНАЛЬНАЯ ТЕХНОЛОГИЧЕСКАЯ ИНИЦИАТИВА
}

\author{
(c) 2018 Щукина Татьяна Владимировна \\ доктор юридических наук, доцент \\ зав. кафедрой административного и финансового права \\ Липецкий филиал РАНХиГС \\ 398050, г. Липецк, ул. Интернациональная, д. 3 \\ профессор кафедры государственно-правовых дисциплин \\ Липецкий государственный педагогический университет \\ 398020, г. Липецк, ул. Ленина, д. 42 \\ E-mail: shukina-tv@mail.ru
}

Предметом настоящей статьи выступает исследование теоретических и практических представлений о процедуре разработки и реализации национальных проектов; рассмотрение новых тенденций формирования национальных проектов, а также особенностей правового регулирования Национальной технологической инициативы. Тема статьи отражает трансформацию правового регулирования применения новых методов государственного управления в проектной деятельности органов государственной власти; разработки инновационных технологических инициатив с помощью государства. Целью настоящей статьи являются выявление на современном этапе специфики разработки и реализации национальных проектов, их содержания и структуры; продвижения технологических инноваций. Методологию данной работы составили сравнительный, формально-юридический, аналитический методы. Результаты работы - это формулирование особенностей разработки и реализации стратегических документов. Область применения результатов работы включает в себя систему государственного и муниципального управления. Выводы исследования могут быть использованы для дальнейшего совершенствования правовой регламентации стратегического управления.

Ключевые слова: национальный проект, структура национального проекта, правовое регулирование национального проектирования, национальная технологическая инициатива.

Процедура разработки и реализации национальных проектов строится на методических указаниях по разработке национальных проектов (программ), утвержденных Правительством РФ от 6 июня 2018 года. Национальные проекты состоят из совокупности федеральных проектов. Достижение целей, целевых и дополнительных показателей и решение задач национального проекта обеспечивается путем исполнения сводного плана мероприятий по реализации национального проекта. Разработка национальных проектов, включая разработку паспортов национальных проектов и паспортов федеральных проектов, в том числе планов мероприятий по реализации федеральных проектов, осуществляется по установленным законодательством формам.

Субъекты проектной деятельности по разработке национальных проектов (программ) аналогичны системе субъектов проектной деятельности, закрепленной в функциональной структуре системы управления проектной деятельностью в Правительстве РФ [1].

Новизна подходов к разработке национальных проектов выражаются в следующем:

- «планирование значений целевых показателей, определенных в Указе Президента РФ от 8 мая 2018 года по годам реализации национального проекта»;

- «включение в национальный проект дополнительных показателей, которые однозначно позволят оценить и достичь цели национального проекта»;

- «дополнение национального проекта задачами, обеспечивающими достижение его целей и целевых показателей» [2];

- «детализация задач до результатов национального проекта;

- «определение контрольных точек, подтверждающих получение результатов национального проекта»;

- «планирование мероприятий, направлен- 
ных на достижение контрольных точек и в совокупности обеспечивающих получение результатов национального проекта»;

- «финансовое обеспечение реализации национальных проектов за счет средств бюджетов всех уровней, а также за счет внебюджетных источников» [3];

- «определение персональной ответственности за достижение целей, целевых показателей, решение задач, достижение результатов и контрольных точек, выполнение мероприятий национальных и федеральных проектов» [4].

Новые требования к национальным проектам:

- «цели и показатели федеральных проектов должны быть направлены на достижение целей, целевых и дополнительных показателей национальных проектов» [5];

- «планы мероприятий по реализации федеральных проектов направлены на решение задач и достижение результатов национальных проектов, соответствующих им контрольных точек в течение 3 лет»;

- «в планы мероприятий по реализации федеральных проектов включаются и мероприятия, учитывающие потребности инвалидов и социально незащищенных групп населения»;

• «планы мероприятий по реализации федеральных проектов подлежат ежегодному уточнению с учетом утвержденных параметров финансового обеспечения реализации соответствующих национальных проектов» [6].

Принципы разработки и реализации национальных проектов федеральными органами государственной власти:

- руководителем национального проекта является руководитель федерального органа исполнительной власти, несущий персональную ответственность за достижение целей, целевых показателей и решение задач национального проекта;

- ответственным лицом за осуществление проектной деятельности по национальным проектам выступает заместитель руководителя федерального органа исполнительной власти, в том числе курирует ведомственный проектный офис;

- «администратором национального проекта является заместитель руководителя федерального органа исполнительной власти;

- формирование ведомственных проектных офисов в федеральных органах исполнительной власти в статусе самостоятельных подразделе- ний с полной занятостью сотрудников и возложением на них задач по организации проектной деятельности;

- действие на основании положений об организации проектной деятельности» [7].

Принципы разработки и реализации нацииональных проектов органами исполнительной власти субъектов РФ:

- закрепление за высшим должностным лицом (руководителем высшего исполнительного органа государственной власти) субъекта РФ ответственности за достижение целей, целевых показателей и решение задач национальных проектов в части, касающейся соответствующего субъекта РФ;

- закрепление за заместителями руководителя высшего исполнительного органа государственной власти субъекта РФ персональной ответственности за достижение целей и показателей федеральных проектов в части, касающейся соответствующего субъекта РФ;

- определение из числа заместителей руководителя высшего исполнительного органа государственной власти субъекта РФ ответственного лица «за организацию проектной деятельности, в том числе в части, касающейся организации работы по реализации национальных и федеральных проектов в субъекте Российской Федерации;

- формирование регионального проектного офиса в органе государственной власти, с возложением на него функций по общей координации реализации национальных и федеральных проектов;

- действие на основании положений об организации проектной деятельности в органах государственной власти субъекта РФ;

- формирование в субъекте РФ региональных проектов, направленных на реализацию национальных и федеральных проектов и достижение соответствующих целей и показателей;

- закрепление в субъекте РФ персональной ответственности за выполнение мероприятий региональных проектов, в том числе в органах местного самоуправления» [8].

По мнению ученых, управление проектами в органах государственной власти отличается от управления проектами в предпринимательской деятельности. Оно носит жесткий правовой характер, подотчетно вышестоящим органам исполнительной власти, финансируется за счет бюджетных ресурсов; подлежит общественному 
контролю и публичной отчетности. И относительно содержания самих проектов, то они масштабны, многогранны, направлены на достижение социального эффекта прежде, чем будет получена выгода от привлечения в него инвестиций. Цели государственных проектов амбициозны и носят долгосрочный характер [9].

Оценить роль этих признаков в практической работе органов исполнительной власти сложно. Однозначного ответа на подобный вопрос: «эффективно или не эффективно», не будет. В настоящее время государство инициирует проекты, предлагает концепции решения стратегических задач развития РФ и социально-экономических проблем. Оно приглашает к их разрешению структуры государственного сектора, частный бизнес и организации общественного сектора, объединяя всех в целях изыскания внутренних ресурсов в достижении поставленных целей. Обеспечивает на 90\% финансирование проектов из федерального бюджета. В этом случае, необходим жесткий контроль за расходованием бюджетных ресурсов, как со стороны государства, так и со стороны общества. Общественные институты контролируют в большей степени реализацию проектов, потому что в первую очередь граждане получают услуги, возможность использования объектов социальной инфраструктуры, информационных площадок и технологий. Без этих инструментов управление государственными проектами бессмысленно.

Инициатива государства по реализации проектов является временным явлением в системе публичного управления, рассчитанного на зарождение самостоятельности и активных решений со стороны бизнеса. В идеальной конструкции публичного управления представители бизнес - сообщества первыми проявляют инициативу по решению социально-экономических вопросов, начиная от строительства дорог и завершая возведением стадионов, больниц, мостов и иных значимых объектов. Государство, в свою очередь, одобряет эти инициативы и при их целесообразности и социальной важности гарантирует реализацию проекта. Это могут быть различного рода гарантии: финансовая, инфраструктурная, информационная, технологическая, правовая и иная поддержка. В условиях санкционных ограничений бизнес, особенно субъекты среднего и малого предпринимательства, не готов самостоятельно выдвигать крупные инициативы и оплачивать их, даже при условии предоставления последующих выплат в возмещение затраченных средств. Подобная ситуация требует государственной поддержки и гарантирования проектов до появления инновационных технологий и креативных идей по формированию собственных инвестиционных ресурсов у предпринимателей, достаточных для разработки и выполнения проектов.

Совместные действия по достижению конкретных результатов проекта в дальнейшем позволят привлечь и иностранные инвестиции, и инвестиции российского бизнеса. И в большей степени за счет кооперации предпринимателей, публичных юридических лиц, органов государственной власти удастся достичь запланированных эффектов. В любом случае прохождение этого этапа развития экономики и публичного управления будет сопровождаться неудачами, ошибками, победами и инновационными решениями.

Безусловно, существуют шероховатости современного процесса управления проектами. Выявляется «несоответствие между реализацией направлений государственной политики в форме проектов и программ с одной стороны и отсутствие методологического и организационного обеспечения управления данными проектами с другой стороны» [10]. Просматриваются проблемы технологической и информационной площадки управления проектами в органах исполнительной власти, но есть уже и положительные практики подобной деятельности (образовательные центры по инклюзивному образованию, строительство больниц и т.п.). Выделены лидеры проектного управления - субъекты РФ: Ленинградская область, Ханты-Мансийский автономный округ - Югра, Белгородская область, Свердловская область и др. В Приморском крае, например, действует Проектный кодекс, утв. постановлением администрации Приморского края от 25.04.2016 № 160-па, а государственные служащие, занимающиеся проектным управлением, мотивированы.

Впервые о Национальной технологической инициативе было сказано в Послании Президента РФ В.В. Путина Федеральному Собранию РФ от 4 декабря 2014 года [11]. Постановлением Правительства РФ от 18 апреля 2016 года N317 «O реализации Национальной технологической инициативы» [12] утверждены Правила разработки и реализации планов мероприятий («дорожных карт») Национальной технологической иници- 
ативы. Для разработки «дорожных карт» НТИ задействован широкий круг субъектов, которые определяют целевые показатели и мероприятия по внедрению НТИ, включая частный сектор. Реализация «дорожных карт» НТИ осуществляется проектами, прошедшими специальный отбор. Проекты помимо государственной финансовой помощи должны иметь еще и внебюджетные источники финансирования, рассчитанные на поддержку государственно-частным партнерством. Стратегический план НТИ и продвижение ее проектов осуществляет «Агентство стратегических инициатив по продвижению новых проектов» (АСИ).

Проекты НТИ разрабатываются и реализуются в целях:

- создания, развития и продвижения передовых технологий, продуктов и услуг, обеспечивающих приоритетные позиции российских организаций на формируемых глобальных рынках;

- поэтапного совершенствования нормативно-правовой базы в целях устранения барьеров для использования передовых технологических решений и создания системы стимулов для их внедрения, совершенствования системы образования;

- обеспечения перспективных кадровых потребностей динамично развивающихся ком- паний, научных и творческих коллективов, участвующих в создании новых глобальных рынков, развития системы профессиональных сообществ.

В организационно-технологическом аспекте НТИ становится глобальным проектом, охватывающим рынки интеллектуальной собственности, технологии, институты и инфраструктуpy. Это [13]: а) десять рынков: AeroNet, AutoNet, EnergyNet, FoodNet, HealthNet, NeuroNet, MariNet; б) университетские города НТИ, в) кружковое движение, г) университет НТИ 2035 , д) олимпиада НТИ и др. Интересные и познавательные мероприятия проводятся в рамках инфраструктурных центров НТИ. С 10 июля 2018 года согласно программе первого образовательного интенсива «Остров 10-21», утвержденной наблюдательным советом АНО «Университет НТИ 2035», было проведено более 1000 мероприятий на о. Русский во Владивостоке. На базе ДВФУ действовали для школьников и студентов лаборатории по квантовым технологиям, машинному обучению, блокчейну, основам цифровой электроники, AR/VR, автоматизации биотехнологических процессов, построению геномных карт, медицинскому интернету вещей, интеллектуальным энергетическим системам, 3D-моделированию, проектированию биометрических сенсоров и робототехнике [14].

\section{Библиографический список}

1. Функциональная структура системы управления проектной деятельностью в Правительстве Российской Федерации, утв. постановлением Правительства РФ от 15 октября 2016 г. № 1050 // Собр. законодательства Рос. Федерации. 2016. N43. Ст. 6028.

2. Методические указания по разработке национальных проектов (программ), утв. Правительством РФ 4 июня 2018 г. N4072п-П6

3. Там же.

4. Там же.

5. Там же.

6. Там же.

7. Там же.

8. Там же.

9. Васильев А.И., Прокофьев С.Е. Организация проектного управления в органах государственной власти // Государственное и муниципальное управление. 2016. № 4. С. 46.

10. Раменская Л.А. Особенности проектного управления в органах государственной власти на региональном уровне // Фундаментальные исследования. 2018. № 1. С. 111-115.

11. Парламентская газета. 2014. 5-11 декабря.

12. О реализации Национальной технологической инициативы: Постановление Правительства РФ от 18 апреля 2016 года N317 // Собр. законодательства Рос. Федерации. 2016. N17. Ст. 2413.

13. Официальный сайт АНО «Агентство стратегических инициатив по продвижению новых проектов». Режим доступа. URL: https://asi.ru/nti/

14. Около 30 технологических лабораторий откроют для участников образовательного интенсива «Остров 1021» в ДВФУ. Режим доступа. URL: https://asi.ru/news/93133/ 